Anna Bednarczyk (D)

Uniwersytet Łódzki

anna.bednarczyk@uni.lodz.pl

\title{
Interdyscyplinarność i przekład - kilka możliwych odpowiedzi
}

Odpowiedź na pytanie o interdyscyplinarność przekładu jest niezwykle trudna choćby dlatego, że nie jest ono jednoznaczne i zawiera w sobie przynajmniej kilka różnych pytań dotyczących przekładu, przekładoznawstwa i interdyscyplinarności. Jest ono także trudne dla badacza, który od wielu lat łączy rozważania teoretyczne z praktycznymi, krytycznymi, analitycznymi studiami, ale też z praktyką tłumaczenia literackiego. Spróbuję jednak podjąć próbę odniesienia się do niektórych z owych pytań, wskazując na kilka możliwych odpowiedzi, bo niejednoznaczność pytań nie pozwala na formułowanie jednoznacznych odpowiedzi. Tym bardziej że w kontekście wielości rodzajów przekładu i podejść do działalności tłumacza, postaw krytycznych i analitycznych, a także mnożących się różnorodnych teoretycznych oglądów interesującego nas zagadnienia ta niejednoznaczność wydaje się oczywista.

Na wstępie chciałabym jeszcze zwrócić uwagę na częste utożsamianie w dyskusji translacji, a więc praktyki tłumaczenia i przekładoznawstwa, czyli nauki o tłumaczeniu. Moim zdaniem utożsamianie takie nie jest uprawnione. O ile translacja - przekład - tłumaczenie jest odrębną praktyką, działaniem, a raczej działalnością zawodową, podobnie jak 
praca literata, mechanika samochodowego albo dentysty, o tyle przekładoznawstwo jest jedną z dyscyplin naukowych niezależnie od tego, czy oficjalnie jest za taką uznawane. Tym bardziej że nie wszędzie, tak jak w Polsce od wielu lat, odmawia się jej prawa do istnienia jako odrębnej dyscyplinie naukowej. Zygmunt Grosbart wspominał swego czasu, że zasadność kreowania przekładoznawstwa jako samodzielnej dyscypliny naukowej podważano, kiedy zaczęło się ono w Polsce kształtować naukowo, na początku lat 60. XX wieku [Grosbart 1996: 57], a wywalczyć należnego przekładoznawstwu miejsca na oficjalnej mapie nauki polskiej nie udało się do dziś. Najczęściej przekładoznawcy uznawani są za lingwistów, rzadziej za literaturoznawców, przy tym dość liczną grupę zdają się tworzyć teoretycy literatury. Ciekawe, że w bazie Nauka polska OPI, w zakładce Ludzie nauki, w opisie specjalności, znajdziemy 101 translatoryków, 94 przekładoznawców, 33 translatologów, 22 teoretyków tłumaczenia, 21 teoretyków przekładu, 10 traduktologów, a ponadto 6 specjalistów z zakresu „teoria i praktyka przekładu” oraz 13 specjalizujących się w dziedzinie przekładu literackiego i po $2 \mathrm{w}$ lingwistyce przekładu oraz w przekładzie ustnym. Wszystko to niezależnie od oficjalnie reprezentowanej dyscypliny, czyli językoznawstwa bądź literaturoznawstwa. Trzeba też zwrócić uwagę na fakt, że owe specjalności dość często się nakładają. Na przykład 15 osób to jednocześnie przekładoznawcy i translatorycy, a 9 reprezentuje aż trzy różne specjalności, a mianowicie przekładoznawstwo, translatorykę i teorię tłumaczenia. Warto też odnotować, że w niektórych wypadkach, przy czym dotyczy to wyłącznie niedawno uzyskanych stopni doktora, ani językoznawstwo, ani literaturoznawstwo wcale nie są przywoływane. Pojawiają się one wyłącznie w opisie rozprawy doktorskiej. Moim zdaniem świadczy to zarówno o potrzebie ujednolicenia nazewnictwa (bo terminologiczne różnicowanie nauki o tłumaczeniu z pewnością jej nie służy, a mnożenie specjalizacji uważam za przykład komizmu niezamierzonego), jak i o potrzebie uznania przekładoznawstwa za odrębną dziedzinę nauki. Wyraźne jest bowiem coraz silniejsze „wyłamywanie” przez badaczy ram narzuconej ustawowo klasyfikacji.

Prawdopodobnie interdyscyplinarne „koneksje” nauki o przekładzie w jakimś stopniu przyczyniły się do opisanego przeze mnie terminologicznego chaosu; mam tu na myśli nie tylko przypisywanie przekładoznawstwa do językoznawstwa bądź literaturoznawstwa, ale także odniesienia go do innych, pozafilologicznych dyscyplin. We wspominanej już bazie ludzi nauki niektórzy badacze przekładu obok filologii 
umiejscawiają swoje zainteresowania w ramach nauk historycznych, filozoficznych bądź teologicznych. Z pewnością postulowanemu ujednoliceniu nie sprzyjały też odmienne tradycje nazewnictwa reprezentowane przez różne filologie (anglojęzyczna translatologia, romańska traduktologia, germańska translatoryka). Nic jednak nie zmienia rzeczywistości badawczej, a ta pozwala mówić o jednej dziedzinie, jaką są badania zorientowane na szeroko rozumiany przekład.

Wrócę jednak do pytań o interdyscyplinarne relacje przekładu i nauki o nim. Przede wszystkim spróbuję odpowiedzieć na pytanie o interdyscyplinarność praktyki zawodowej. Moim zdaniem odpowiedź na nie jest tak oczywista, że pytanie staje się absurdalne. Jeśli bowiem spróbujemy postawić takie pytanie w stosunku do dowolnej działalności praktycznej, okaże się, że żadnej nie można wyizolować i nie zauważać jej powiązań z działaniem (działaniami) innego rodzaju. Na przykład z działalnością wspomnianego wcześniej dentysty musimy kojarzyć jego wiedzę medyczną, ale także chemiczną, a w wypadku, gdy jest on protetykiem, winniśmy zapewne oczekiwać choćby pewnej dozy artyzmu, musi on przecież np. dobrać kolor protezy. Z kolei mechanik powinien charakteryzować się wiedzą z zakresu matematyki, fizyki, a może także umiejętnościami praktycznymi na pograniczu kowalstwa i sztuk pięknych, skoro trzeba choćby pięknie wyklepać karoserię. O literacie mówić nie będę, uznając, że wszyscy rozumieją choćby taki problem, jak konieczność wiedzy historycznej podczas pisania powieści historycznej, psychologicznej w wypadku powieści psychologicznej itd. Zdaję sobie przy tym sprawę, że przywoływanie wszystkich wspomnianych przeze mnie zawodów i wskazywanie ich interdyscyplinarnych powiązań można uznać za demagogię, przywołuję je jednak świadomie, pragnąc ukazać problem, jakim jest dla mnie konieczność dowodzenia rzeczy oczywistej. Nie ma bowiem żadnej profesji istniejącej bez powiązania z inną: $\mathrm{z}$ charakterystyczną dla niej wiedzą bądź umiejętnościami, a czasem wykorzystującą $\mathrm{i}$ jedno, i drugie. Tak jest też z thumaczeniem, a przede wszystkim z tłumaczem, który w konkretnych wypadkach musi zwracać się do wiedzy $\mathrm{z}$ zakresu różnych profesji. W tym do wiedzy z zakresu przekładoznawstwa, nawet jeśli sam sobie tego nie uświadamia. $Z$ drugiej jednak strony nikt nie zastanawia się nad tym, czy tłumacz to zawód odrębny, czy może jest połączeniem innych zawodów. Pomijam wcześniejsze epoki historyczne, kiedy tłumacz poezji miał być poetą, jak choćby za czasów romantyzmu, choć niektórzy uważają tak nawet dzisiaj i w jakimś sensie 
mają rację. $\mathrm{W}$ takim mianowicie, że bez pewnego talentu poetyckiego przekładowcy nie uda się dokonać translacji wiersza, bo nie potrafi np. odnaleźć rytmu, melodii, rymu. Co więcej, zależność ta o wiele wyraźniej widoczna jest w wypadku thumaczy specjalistycznych, kiedy poza konieczną znajomością obu języków potrzebna jest znajomość terminologii, a często także rozumienie specyfiki danego zawodu. Uważa się powszechnie, że najlepszym tłumaczem tekstów prawniczych jest prawnik znający dany język, a tekstów technicznych - inżynier ze znajomością języka. Pozwolę sobie powiedzieć, że zdarzyło mi się przekładać teksty techniczne i o ile zapoznanie się z profesjonalną terminologią uważam za możliwe, przy pewnym nakładzie pracy i czasu, o tyle zrozumienie pewnych procesów technicznych to już zupełnie inna kwestia. Dlatego w wielu wypadkach wspomagałam się wiedzą specjalistów, traktując taką współpracę za ze wszech miar korzystną, a nawet niezbędną. Czy to interdyscyplinarność? A może naturalne dla odpowiedzialnego thumacza wykorzystywanie wszelkiej dostępnej wiedzy i umiejętności, w tym uzyskiwanie wiedzy niezbędnej do dokonania konkretnego przekładu? Dotyczy to również tłumaczenia literackiego. Czy o interdyscyplinarności praktyki tłumaczenia świadczą np. biograficzne poszukiwania dotyczące autora oryginału albo zainteresowanie daną epoką literacką i językiem, jakim został napisany tłumaczony przez niego tekst? Moim zdaniem wszystko to potwierdza raczej przekonanie o potrzebie szerokiej wiedzy, dostosowanej do przekładanego tekstu, do jego specyfiki. Wracamy więc choćby do propozycji Kathariny Reiss [Райс 1978: 202-228] oraz Barbary Kielar [Kielar 1988: 34-35], które wskazywały na konieczność dostosowania praktyki przekładowej do najważniejszej funkcji pełnionej przez tekst źródłowy oraz do podziału tekstów na informacyjne, apelatywne i artystyczne. W zależności od rodzaju tekstu, uzależnionego od pełnionej przez ten tekst funkcji, tłumaczowi potrzebna jest wiedza z zakresu innej dyscypliny. Jest ona konieczna zarówno na pierwszym etapie pracy, jakim z mojego punktu widzenia jest analiza pretranslatorska tekstu oryginału, jak i na etapie drugim, a więc w procesie thumaczenia.

Powyższe konstatacje postaram się zilustrować na przykładzie kilku elementów obserwowanych w rosyjskim tekście wyjściowym i odpowiadających im fragmentów polskiego przekładu mojego autorstwa, co pozwoli zaprezentować proces analizy wstępnej, przygotowującej tłumacza do dokonania translacji. 
Pierwszym z nich jest tytuł, który określa charakter danego tekstu niezależnie od jego rodzaju, co odnosi się także do utworu literackiego. Taki stosunek do tytułu prezentują liczni badacze, a przykładem mogą być rosyjscy literaturoznawcy: Natalia Wiesiołowa, która uważa, że tytuł należy „rozpatrywać jak szczególnego rodzaju imię własne, w ramach onomastyki podobnie jak toponimy i antroponimy"' [Веселова 1998: 19-20], czy Walerij Tiupa, który zauważa, że w tytule tekstu, rozumianym jako imię własne danego utworu, obserwujemy trzy najważniejsze intencje:

[r]eferencyjną, a więc relację tekstu i świata artystycznego [...]; kreacyjną, czyli relację tekstu $\mathrm{z}$ wewnętrzną wolą autora jako organizatora pewnego zdarzenia komunikacyjnego; receptywną, która jest relacją tekstu ze współtwórczym współprzeżywaniem czytelnika jako potencjalnego realizatora tego zdarzenia komunikacyjnego ${ }^{2}$ [Тюпа 2001: 143].

$\mathrm{Z}$ mojego punktu widzenia potencjalnego tłumacza powinna interesować przede wszystkim trzecia z nich, ponieważ wymusza ona dążenie do upodobnienia reakcji czytelniczej odbiorcy produktu docelowego do reakcji czytelnika oryginału. Zdając sobie sprawę z niemożliwości uzyskania reakcji tożsamej, zakładamy dążenie do zbliżenia reakcji tych dwu różnych kulturowo odbiorców, a co za tym idzie - dążenie do upodobnienia ich współprzeżywania i współtworzenia. Konsekwencją takiego działania jest kształtowanie podobnych skojarzeń. Zilustruję to na przykładzie tłumaczenia dwóch tytułów, które wymuszają odniesienie się do wiedzy pozajęzykowej. Pierwszy z nich to tytuł jednego z sonetów Igora Siewierianina z cyklu Medaliony, a mianowicie sonetu zatytułowanego T.A. Гофман. Wiersz ten został poświęcony niemieckiemu pisarzowi, poecie i kompozytorowi Ernstowi Theodorowi Wilhelmowi Hoffmannowi, który wielbił muzykę Mozarta tak bardzo, że na jego cześć zmienił swoje trzecie imię Wilhelm na Amadeus - stąd inicjał A (E. T. A. - Ernst Theodor Amadeus). Trudno stwierdzić, dlaczego Siewierianin pominął w tytule inicjał pierwszego imienia, niemniej uznałam, że polskiemu czytelnikowi należy zaprezentować wszystkie trzy imiona Hoffmanna, co sprzyjać będzie też jego identyfikacji. Dlatego tytuł polski brzmi

\footnotetext{
1 „рассматривать его, как собственное имя особого рода, в рамках общей ономастики, подобно топонимам или антропонимам”.

2 „референтная - соотнесенность текста с художественным миром: с внешним хронотопом бытия героя или с самим героем (внутренним хронотопом); креативная - соотнесенность текста с творческой волей автора как организатора".
} 
E. T. A. Hoffmann. Tłumacząc go, sięgnęłam więc do wiedzy pozajęzykowej, a moje poszukiwania można uznać za interdyscyplinarne, ponieważ dotyczyły one postaci historycznej i związanych z nią realiów. Podobnie stało się w wypadku tytułu wiersza Mariny Cwietajewej Генералам 1812 года (po polsku Generałom 1812 roku). Przystępując do jego przekładu, tłumacz winien uwzględnić wymienioną w tytule datę, ponieważ wskazuje ona na wojnę Rosji z Napoleonem. Idzie tu o wojnę, która rozpoczęła się 12 czerwca 1812 roku, kiedy wojska francuskie przekroczyły Niemen, w historiografii rosyjskiej znaną jako wojna ojczyźniana 1812 roku. Warto przy tym odnotować, że w tym czasie generałami często zostawali młodzi oficerowie, którzy odznaczyli się na polu walki. Wiersz, o którym mowa, poza tytułem określa jeszcze dedykacja Сергею (Siergiejowi), którą trudno pominąć, tym bardziej że odnosi się ona nie do generała 1812 roku, ale do męża Cwietajewej, Siergieja Efrona. Jedyne, co może uczynić tłumacz, to w ewentualnym komentarzu wyjaśnić, kim jest adresat dedykacji. Tym razem poszukiwania translatorskie dotyczą więc zarówno faktów historycznych, jak i biograficznych.

Przejdźmy jednak do głównego tekstu, pozostając przy dwóch wspomnianych utworach Siewierianina i Cwietajewej. Pierwszy z nich poświęcony jest twórcy najwyraźniej szanowanemu przez rosyjskiego poetę, o czym świadczy także inne nawiązanie do tej postaci, a mianowicie wiersz zatytułowany Эпизод (Epizod). W Epizodzie pojawiły się takie elementy wskazujące na twórczość Hoffmanna jak: tytuł opery Jacques'a Offenbacha Opowieści Hoffmanna, dla której kanwą stały się opowiadania niemieckiego autora, jedna $\mathrm{z}$ bohaterek wspomnianej opery Olimpia, fragment sceny $z$ drugiego aktu i nawiązanie do aktu piątego, a nawet nazwisko Hoffmann. Nas jednak interesuje sonet z cyklu Medaliony, w którym poza tytułowym nazwiskiem, obecnym też w ostatnim wersie, nie obserwujemy żadnych wyraźnych wskazań na pisarza. Znajdujemy w nim jednak pośrednie odwołania do jego twórczości - liczne wypowiedzi nawiązujące do grozy, strachu, a więc nastroju, jaki Hoffmann tworzył w swoich opowiadaniach fantastycznych, i które właśnie dlatego wymagają odtworzenia w przekładzie. Poza tym w sonecie pojawia się wskazanie na marzenie, które kocha niemiecki poeta, czego wyraz znajdujemy przede wszystkim w Opowieściach Hoffmanna, ale przecież i w Dziadku do orzechów, który jest równie fantastyczny, co miejscami przerażający. Przekład nie musi dokładnie powtarzać słów oryginału, powinien jednak budować podobny system nawiązań. Poniżej prezentuję 
kilka z nich w obu wariantach językowych, z wytłuszczeniami wskazującymi miejsca, które traktowane jako siatka nawiązań do twórczości Hoffmanna wymagały z jednej strony interdyscyplinarnych poszukiwań w socjokulturowym polisystemie oryginału, $\mathrm{z}$ drugiej zaś stały się w tekście tłumaczenia odpowiedzią na ten system nawiązań:

\begin{tabular}{|c|c|}
\hline Oryginal & Tłumaczenie poetyckie \\
\hline $\begin{array}{l}\text { Вокруг нас жуть: в трагичном } \\
\text { и смешном, } \\
\text { В сопутнике живом таится призрак. } \\
\text { Фарфор бездушный часто больше } \\
\text { близок, } \\
\text { Чем человек. И стерта грань меж } \\
\text { сном. }\end{array}$ & $\begin{array}{l}\text { Budzą w nas grozę komedia i dramat, } \\
\text { Upiór się w żywym przyjacielu skrywa. } \\
\text { I porcelana bliżzza nam nieżywa } \\
\text { Niż człek. Zniknęla pomiędzy snem } \\
\text { brama. }\end{array}$ \\
\hline Любить Мечту и то порой грешно. & $\begin{array}{l}\text { Kochać Marzenie też może być } \\
\text { grzechem. }\end{array}$ \\
\hline $\begin{array}{l}\text { Как прорицательна болезнь } \\
\text { фантаста, } \\
\text { Ведущая здоровых к бездне часто, } \\
\text { Сокрытой их здоровьем от очей. }\end{array}$ & $\begin{array}{l}\text { Tak jak fantasta w proroczej } \\
\text { chorobie, } \\
\text { Który do zguby wiedzie tych, co } \\
\text { zdrowi, } \\
\text { Skrywając obłęd przed rozsądku okiem. }\end{array}$ \\
\hline $\begin{array}{l}\text { Не величайший ли из всех великих } \\
\text { Поэтов Гофман в ужасе речей? }\end{array}$ & $\begin{array}{l}\text { Może największym był ze wszystkich } \\
\text { wielkich } \\
\text { Poetów - Hoffmann, sącząc grozę } \\
\text { w mroku? }\end{array}$ \\
\hline
\end{tabular}

Nie omawiam tu swojego przekładu, w którym znalazły się różnego rodzaju transformacje, moim celem jest bowiem ukazanie elementów tekstu źródłowego wymagających od tłumacza poszukiwań w sferze pozafilologicznej, w danym wypadku dostosowania translacji do obecnych w oryginale nawiązań do twórczości Hoffmanna.

Przejdźmy jednak do drugiego z wymienionych tekstów. Składa się on z dwu części, z których pierwsza nie wymaga specjalnych poszukiwań translatorskich. Poza dwoma nawiązaniami do munduru, jakimi są широкие шинели (szerokie szynele, płaszcze wojskowe) i шпоры (ostrogi), nie znajdziemy w nim żadnych szczególnych zjawisk z zakresu języka podstandardowego (wymienione można uznać za profesjonalizmy). 


\begin{tabular}{|l|l|}
\hline Oryginał & Tłumaczenie poetyckie \\
\hline Вы, чьи широкие шинели & Waszych wojskowych płaszczy poły \\
Напоминали паруса, & Jak skrzydła żagla szarpał los, \\
Чьи шпоры весело звенели & Ten waszych ostróg brzęk wesoły \\
И голоса $[\ldots]$ & I głosów moc $[\ldots]$ \\
\hline
\end{tabular}

W tłumaczeniu obserwujemy niewielkie poszerzenie obrazu i wprowadzenie jeszcze jednego profesjonalnego elementu, a mianowicie obraz chłopców, którzy teraz są oficerami, uzupełniłam, wprowadzając oficerskie pagony, co jest zgodne z realiami epoki i nie burzy obrazu zbudowanego przez Cwietajewę:

\begin{tabular}{|c|c|c|}
\hline Oryginal & $\begin{array}{l}\text { Tłumaczenie } \\
\text { filologiczne }\end{array}$ & Tłumaczenie poetyckie \\
\hline $\begin{array}{l}\text { Вас охраняла длань } \\
\text { Господня } \\
\text { И сердце матери. } \\
\text { Вчера - } \\
\text { Малютки-мальчики, } \\
\text { сегодня - } \\
\text { Офицера. }\end{array}$ & $\begin{array}{l}\text { Chroniła was Boska ręka } \\
\text { I serce matki. Wczoraj - } \\
\text { Malcy-chłopcy, dzisiaj - } \\
\text { Oficerowie. }\end{array}$ & $\begin{array}{l}\text { Bóg bronił was i matki } \\
\text { serce. } \\
\text { Wojna dla chłopców } \\
\text { była grą - } \\
\text { Dziś na mundurze } \\
\text { oficerskie } \\
\text { Pagony lśnią. }\end{array}$ \\
\hline
\end{tabular}

Nie znaczy to, że w tekście nie ma innych interesujących dla thumacza zjawisk. Trudno jednak mówić o interdyscyplinarności w wypadku budowy wiersza, gry słów, organizacji brzmieniowej. Natomiast w płaszczyźnie kulturowej zwraca uwagę podkreślanie udziału oficerów zarówno w walce, jak i na balach oraz młodego wieku generałów. Wiedza ta jest potrzebna o tyle, o ile warto określić dominanty przekładu, a z pewnością należą do nich realia epoki.

Druga część wiersza Cwietajewej nie odbiega nastrojem od pierwszej, jednak pojawia się w niej konkretny generał, a raczej jego portret. Idzie o generała Aleksandra Aleksiejewicza Tuczkowa IV, który zginął w bitwie pod Borodino w 1812 roku, i o jego pośmiertny portret autorstwa George'a Dawe'a ${ }^{3}$, wiszący w Galerii Wojskowej w petersburskim Pałacu Zimowym. Dawe w latach 1819-1829 pracował w Sankt Petersburgu,

3 G. Dawe, Portret A.A. Tuczkowa IV, https://commons.wikimedia.org/w/index. php?curid=1685949. 
gdzie $\mathrm{z}$ pomocą dwu rosyjskich artystów ${ }^{4}$ namalował ponad 300 portretów rosyjskich bohaterów wojny 1812 roku. Warto poznać te fakty przed przystąpieniem do przekładu wiersza. Niemniej nie oznacza to wcale konieczności odtworzenia całego opisu Cwietajewej, ani nawet nazwiska generała, ponieważ polskiemu czytelnikowi, nawet jeśli orientuje się w historii i kojarzy datę $1812 \mathrm{z}$ wojną rosyjsko-francuską, generał Tuczkow IV nie kojarzy się z niczym. Z mojego punktu widzenia jako tłumacza warto byłoby jednak zobaczyć portret, jeśli nie chcemy zastąpić kędzierzawego blondyna równie przystojnym wprawdzie, ale brunetem:

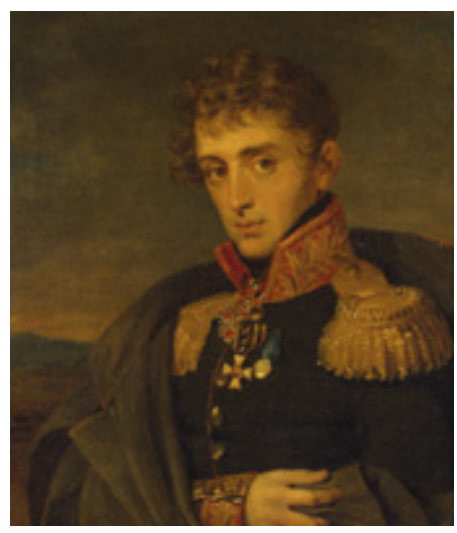

George Dawe, Portret A.A. Tuczkowa IV

\begin{tabular}{|c|c|c|}
\hline Oryginal & $\begin{array}{l}\text { Tłumaczenie } \\
\text { filologiczne }\end{array}$ & Tłumaczenie poetyckie \\
\hline $\begin{array}{l}\text { Ах, на гравюре } \\
\text { полустёртой, } \\
\text { В один великолепный } \\
\text { миг, } \\
\text { Я видела, } \\
\text { Тучков-четвёртый, } \\
\text { Ваш нежный лик, }\end{array}$ & $\begin{array}{l}\text { Ach, na rycinie na wpół } \\
\text { startej, } \\
\text { W jednej wspaniałej } \\
\text { chwili, } \\
\text { Ujrzałam, } \\
\text { Tuczkowie-czwarty, } \\
\text { Pana delikatną twarz, }\end{array}$ & $\begin{array}{l}\text { Na wpółwytartym } \\
\text { medalionie } \\
\text { Twój obraz zobaczyłam } \\
\text { raz, } \\
\text { Widziałam loki na twych } \\
\text { skroniach } \\
\text { I miłą twarz, }\end{array}$ \\
\hline $\begin{array}{l}\text { И вашу хрупкую } \\
\text { фигуру, } \\
\text { И золотые ордена... } \\
\text { И я, поцеловав гравюру, } \\
\text { Не знала сна. }\end{array}$ & $\begin{array}{l}\text { I pana kruchą figurę, } \\
\text { I zlote ordery... } \\
\text { I pocałowawszy rycinę, } \\
\text { Nie mogłam spać. }\end{array}$ & $\begin{array}{l}\text { Mój generale, postać } \\
\text { całą, } \\
\text { Na piersi order - zlota } \\
\text { gładź... } \\
\text { I ten medalion } \\
\text { całowałam, } \\
\text { Nie mogłam spać. }\end{array}$ \\
\hline
\end{tabular}

4 Dawe korzystał z pomocy swych uczniów: Wilhelma Augusta (Wasilij Aleksandrowicz) Golike i Aleksandra Poliakowa. 


\begin{tabular}{|l|l|l|}
\hline В одной невероятной & W jednym niebywałym & Tyś jednym niebywałym \\
скачке & skoku & skokiem \\
Вы прожили свой & Przeżył Pan swój krótki & Przeżył krótkiego życia \\
краткий век... & czas... & bieg... \\
И ваши кудри, ваши & A pańskie loki, pana & A twoje baczki, twoje \\
бачки & baczki & loki \\
Засыпал снег. & Zasypał śnieg. & Zasypał śnieg. \\
\hline
\end{tabular}

Dla niniejszych rozważań można było wybrać inne teksty, bardziej „wyraziste interdyscyplinarnie”, np. utwory słowno-meliczne, których tłumaczenie wymusza zwrócenie się ku płaszczyźnie muzycznej, bądź wiersze należące do poezji konkretnej, gdzie poszukiwalibyśmy odpowiedników graficznych. Ekfrastyczne nawiązanie, jeśli można tak nazwać wiersz Cwietajewej, wymaga wprawdzie przyjrzenia się portretowi Tuczkowa. Polskiemu odbiorcy wystarczy jednak wskazanie na portret i przystojnego generała. Możliwe, że jego kruchość, delikatne rysy, o czym pisze poetka, nawiązują do Siergieja Efrona, któremu dedykowany jest wiersz, a który był chorowitym (miał gruźlicę), szczupłym i bladym mężczyzną. Swietłana Makarienko w biograficznej książce poświęconej Ariadnie Efron (córce Mariny i Siergieja) tak opisywała pierwsze spotkanie Cwietajewej i jej przyszłego męża:

[...] wysoki, chorobliwie blady, z wyraziście głębokimi oczyma (później wszyscy, przez całe życie poznawali go właśnie po nich - po oczach!) ${ }^{5}$ [Макаренко 2002: on-line].

Można było także zaprezentować teksty z nagromadzeniem słownictwa podstandardowego i zastanawiać się nad koniecznością poszukiwań translatorskich z zakresu socjologii czy socjolingwistyki, gdyby pojawiły się w nich dialektyzmy, profesjonalizmy bądź żargonizmy, jak choćby w Cichym Donie Michaiła Szołochowa, gdzie znajdziemy dialekt Kozaków, w Opowiadaniach odeskich Izaaka Babla, które obfitują w leksykę należącą do języka jidysz, czy w nasyconej słownictwem potocznym Moskwie-Pietuszkach Wieniedikta Jerofiejewa. Czasem chodzi o jeden element, o jedno słowo. Pozwolę sobie przytoczyć dwa własne przykłady poszukiwań, a mianowicie z jednej strony ,telefon ratunkowy do znajomego", aby zapytać, czy po polsku siekiera ma policzki, bo pojawiły się

\footnotetext{
[...] высокий, болезненно бледный, с выразительно - глубокими глазами (его потом все и всю жизнь узнавали по ним - глазам!).
} 


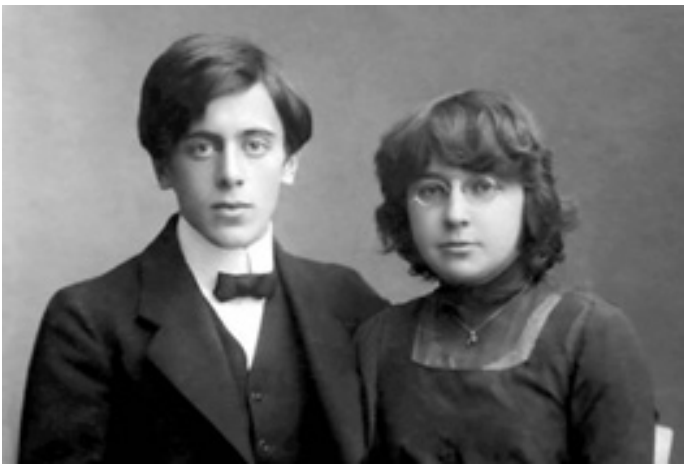

Marina Cwietajewa i Siergiej Efron, 1911

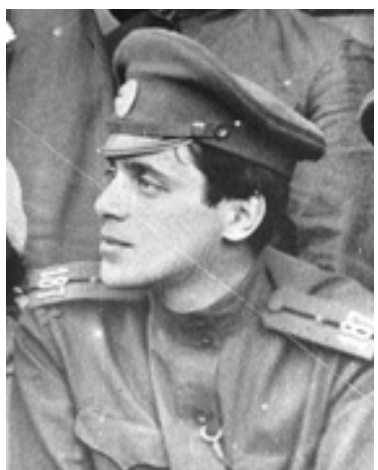

Siergiej Efron 1915 (w pociągu sanitarnym $\mathrm{nr}$ 187)

w tekście rosyjskim, a z drugiej - wyznaczenie strategii przekładu przez składowe centonu, a więc kombinacji różnych tekstów, które mogą należeć do różnych kodów semiotycznych, jak w wypadku centonu Michaiła Wakslera Экологическое одностишие (Ekologiczny jednowiersz). W jego wypadku jako współautorzy ukazani zostali Ilja Riepin i Aleksiej Sawrasow [Wiksler: on-line], ponieważ wiersz jest złożeniem dwu tytułów obrazów: Грачи прилетели... (Przyleciały gawrony) Aleksieja Sawrasowa ${ }^{6}$ і Не ждали (Nie oczekiwali...) Ilji Riepina ${ }^{7}$.

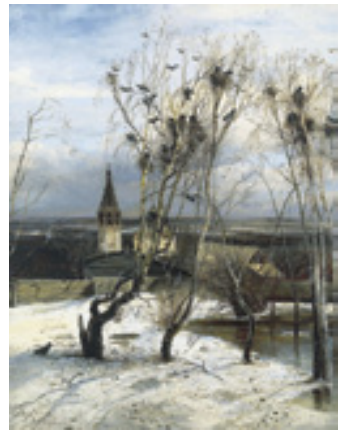

A. Sawrasow, Przyleciaty gawrony

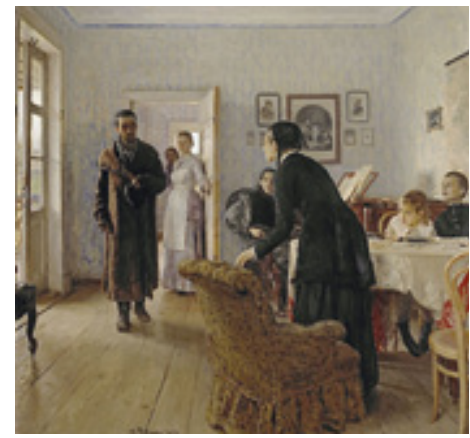

I. Riepin, Nie oczekiwali...

\footnotetext{
А. Саврасов, Грачи прилетели, http://alexey-savrasov.ru/kartina/1.php.

И. Репин, Не ждали, http:/www.tanais.info/art/repin40more.html.
} 
Wiersz ten brzmi: „Грачи прилетели... Не ждали” і wyznacza jedyny możliwy przekład: „Przyleciały gawrony... Nie oczekiwali”. Wyliczać tak można w nieskończoność. Nie chciałam jednak rozpatrywać tego typu tekstów, ponieważ odniesienia do sfer pozaliterackich w utworach literatury pięknej uważam za oczywiste, czego konsekwencją są interdyscyplinarne, czy może raczej polisemiotyczne (wymagające łączenia dwu lub więcej kodów semiotycznych) poszukiwania tłumacza, który dąży do odtworzenia konkretnego stylu, nastroju bądź orientacji na danego czytelnika, jak choćby w wypadku tekstów dla dzieci.

Przejdźmy jednak do kolejnej interesującej nas dziedziny - przekładoznawstwa, a więc tej dyscypliny naukowej, dla której przedmiotem badawczym jest przekład, na co wskazywał np. dowodzący samodzielności teorii thumaczenia Jerzy Pieńkos [Pieńkos 1993: 30-31]. Przy tym przekład rozumiany zarówno jako proces translacji, jak i rezultat tego procesu. Tu odpowiedź na pytanie o interdyscyplinarność wydaje się równie oczywista. Zwykle na jednych z pierwszych zajęć z teorii thumaczenia wyjaśniamy studentom, że przekładoznawstwo czerpie i z językoznawstwa, i z literaturoznawstwa, i z socjologii, i z psychologii, a nawet z informatyki - w 1965 roku Jerzy Ziomek opublikował nawet książkę, prezentując takie właśnie podejście do badań przekładoznawczych. Nosiła ona tytuł Staff $i$ Kochanowski: próba zastosowania teorii informacji w badaniach nad przektadem. Z kolei Tatiana Klonowicz, poświęcając monografię pracy tłumacza kabinowego, wskazywała na zależność przekładu od psychiki translatora. Tu jednak odchodzimy od przekładu literackiego, choć wydaje mi się, że tłumaczowi literackiemu stres również towarzyszy, może nie tak silny doraźnie, ale uporczywy, bo rozciągnięty w czasie.

Podsumowując, moim zdaniem korzystanie nauki o thumaczeniu z metod czy terminów znanych wcześniej innym dyscyplinom naukowym oznacza wprawdzie interdyscyplinarność, ale nie zmienia faktu, iż jest to dziedzina odrębna. W przeciwnym razie cała nauka byłaby filozofią, z której wyrosła. Uważam też, że interdyscyplinarność, a raczej wykorzystywanie interdyscyplinarnych możliwości, sprzyja rozwojowi nauki, w tym nauki o przekładzie.

Z przedstawionych tu rozważań wynika więc, że powinniśmy pytać nie tyle o interdyscyplinarność przekładu i przekładoznawstwa, ile o to, jak wykorzystywać inne badania i dziedziny w praktyce i w analizie przekładowej. Na pytanie, jakie miałyby to być dziedziny, odpowiedź brzmi: 
wszelkie potrzebne, czyli konieczne do dokonania dobrego (akceptowalnego) przekładu oraz do przeprowadzenia rzetelnych - opartych na specjalistycznej wiedzy i analizie - badań. W przeciwnym wypadku nie jest to możliwe.

Dlatego też granicę przekładoznawstwa widzę tam, gdzie nie będzie mowy o studiach nad tłumaczeniem intralingwistycznym, interlingwistycznym oraz inter-, ale też intrasemiotycznym, o którym pisał Edward Balcerzan [Balcerzan 2009: 245-247]. Analizując propozycję Peetera Toropa, który uważał recepcję za przekład całkowity ${ }^{8}$ :

przekład pozostaje częścią ogólnych receptywnych procesów w kulturze, a recepcja - całkowitym przekładem, w którym tłumaczenie tekstów sąsiaduje z innymi adaptującymi i specyfikującymi kanałami przenikania jednej kultury do innej [Torop 2008: 171],

polski badacz wyjaśniał, że „Obiektem procesu tłumaczenia może być jedynie tekst”, którego kontekstem i tworzywem „musi być porządek paradygmatyczny" [Balcerzan 2009: 248-249], a więc ,język źródłowy, w którym poddawany tłumaczeniu tekst został uformowany" [ibidem: 249], a ponadto:

nieodzowne jest istnienie innego niż pierwotny porządku paradygmatycznego, zwanego językiem docelowym, oraz uformowanie w tym nowym języku nowego tekstu, zasadniczo respektującego podstawowe syntagmatyczne oraz semantyczne wyznaczniki tożsamości oryginału [ibidem: 249].

Można przyjąć, że tak rozumiana definicja przekładu określa nie tylko granice tego procesu, a więc praktycznej działalności tłumacza, ale również ramy nauki o przekładzie, o ile przyjmiemy, że nauka ta odnosi się do tak zakreślonych granic przedmiotu, który bada. Niemniej w żadnym razie nie wyklucza to interdyscyplinarności praktyki ani teorii.

Cytowany już Grosbart, którego niezrealizowanym marzeniem było powstanie przekładoznawstwa jako niezależnej dyscypliny naukowej, rozważając możliwość opracowania „użytecznej” teorii przekładu, jak ją nazywał, pisał dwadzieścia lat temu, że winna to być teoria otwarta na różne koncepcje translatologiczne i ,swobodnie czerpiąca z nich wszystko, co może być użyteczne dla tłumacza" [Grosbart 1998: 54]. Rok później, próbując określić, czym jest przekład, i odnosząc się do jego praktyki,

8 Tytuł rosyjski Тотальный перевод тоżna też tłumaczyć jako „przekład totalny”. 
konstatował: „Jeśli sztuka przekładu ma być skuteczna, to jej podstawy naukowe powinny być otwarte na wszelkie koncepcje translatologiczne" [Grosbart 1999: 23].

Trawestując te słowa i myśli, pozwolę sobie powiedzieć, że jeśli sztuka przekładu ma być skuteczna, to zarówno praktyka, jak i jej podstawy naukowe, a więc badania teoretyczne, powinny być otwarte na wszelkie inne dziedziny i swobodnie czerpać z nich to, co użyteczne dla tłumacza oraz dla rozwoju nauki o tłumaczeniu. Interdyscyplinarność nie jest dla mnie nakazem, jest możliwością, choć w niektórych wypadkach staje się koniecznością.

Czasem, o czym już wspominałam na wstępie, przekład adekwatny do oryginału (myślę tu o adekwatności w sensie makrotekstu), a co za tym idzie - proces translacji, wymaga specjalistycznej profesjonalnej wiedzy, o czym stosunkowo często piszą specjaliści parający się tłumaczeniem specjalistycznym. Przypomnę w tym miejscu starą, aczkolwiek niezwykle cenną pracę Andrzeja Voellnagla Jak nie ttumaczyć tekstów technicz$n y c h$, której autor ukazywał, w jaki sposób braki owej wiedzy wpływają na rezultat przekładu, ale dowodził też potrzeby szerokich kulturowych kompetencji przekładowcy, także w wypadku translacji tekstów technicznych. Swego czasu furorę wśród adeptów sztuki tłumaczenia robił cytowany przez niego przykład, a mianowicie „A bare conductor runs along the train”, co przełożono na język polski: „Nagi konduktor biegnie wzdłuż pociągu". W komentarzu badacza czytamy:

Nieprzystojny wydźwięk spowodowało tu podobieństwo słów „conductor” i ,konduktor”, w rzeczywistości chodziło, zaś o nieizolowany przewód elektryczny, należący do układu hamulcowego pociągu [Voellnagel 1973: 71].

Pomijając oczywiste słownikowe thumaczenie, musimy konstatować, że minimum wiedzy technicznej pozwoliłoby przekładowcy uniknąć błędu.

W innych wypadkach potrzebna jest także wiedza z zakresu konkretnej bądź też szeroko pojmowanej kultury. Voellnagel widział tę potrzebę także przy tłumaczeniu tekstów technicznych, dlatego wskazywał błędy wynikające z braku wykształcenia klasycznego, jak transkrypcja łacińskiego wyrażenia in situ, czyli na miejscu (w danym miejscu), wprowadzająca do tekstu niezrozumiały element i burząca logikę wypowiedzi: 
1. Regenerowanie kontaktu można przeprowadzić w situ... [ibidem: 10];

2. W szczególnych przypadkach, które wykluczają regenerowanie w situ, katalizator może być regenerowany u producenta [ibidem: 11].

Nie będę tu prowadzić rozważań na temat tego, czy tłumacz, stosując się do propagowanej przez Voellnagla „zasady maksymalnej niejasności”, która brzmi:

Przełożyć tekst w dokładnie tak samo niejasnej formie, tj. umożliwiając czytelnikowi zrozumienie przekładu w równie dowolny sposób, jak to było możliwe w przypadku oryginału [ibidem: 146],

maskował w ten sposób swoje niezrozumienie tekstu. Tym bardziej że wspomnianą zasadę autor zalecał w wypadku niejasnego sformułowania oryginału, a nie braków wiedzy tłumacza. Nie będę również zastanawiać się, czy „w situ” miało być odmienionym tak dziwnie sformułowaniem „W sieci”, a może „w sicie”. Niemniej i tutaj minimum wiedzy technicznej kazałoby się zastanowić nad przekładem. Zacytuję jeszcze jeden przykład pochodzący z tejże pracy i dowodzący potrzeby posiadania wykształcenia ogólnego, a mianowicie tłumaczenie zdania „Illiac Suite for String Quartet” jako „suita Illiaca dla kwartetu Stringa” zamiast „suita Illiaca na kwartet smyczkowy" [ibidem: 12].

Powyższe rozważania dowodzą konieczności dysponowania przez tłumacza wiedzą wychodzącą poza zakres wąskiej specjalizacji, zarówno specjalistyczną, jak i ogólnokulturową. Odpowiadają także twierdząco na pytanie o potrzebną tłumaczowi wiedzę pozajęzykową i pozatekstową, a w jakimś stopniu stanowią również odpowiedź na pytanie o widzenie przekładu z różnych perspektyw badawczych. Najwyraźniej jest to możliwe zarówno z punktu widzenia realizacji przez tekst docelowy informacji profesjonalnej czy kulturowej, jak i informacji w ogóle.

Nasuwa się jednak pytanie o to, czym jest perspektywa translatorska. Czy można mówić o perspektywie translatorskiej i nietranslatorskiej? Moim zdaniem pytanie o różnicę tych oglądów jest niefortunne. Możemy oczywiście założyć, że perspektywa translatorska to ta, która dotyczy adekwatności tekstu docelowego w stosunku do źródłowego i jego akceptowalności w kulturze docelowej. Przy tym akceptowalność zawiera zakładany przez tłumacza stopień percepcji i wynikającą z niej reakcję odbiorcy. Wszelkie inne widzenie przekładu znajdzie się wtedy poza perspektywą translatorską. Wracając do pytania o różnicę perspektyw, trzeba 
stwierdzić, że odpowiedź nie może być jednoznaczna. Z jednej strony winna ona brzmieć TAK - z perspektywy translatorskiej tekst brzmi dobrze, został napisany poprawnym językiem, oddaje informację, artyzm bądź nastrój, jest adekwatny do oryginału w płaszczyźnie semantycznej, pragmatycznej albo syntaktycznej, odtwarza charakterystyczne dla przekładanego oryginału zjawiska lingwistyczne czy stylistyczne, takie jak liczne dialektyzmy, archaizmy, występującą w tekście terminologię profesjonalną. Zauważmy przy tym, że tak rozumiana perspektywa translatorska zależy od funkcji pełnionej przez dany tekst źródłowy, który został osadzony w pewnym czasie i w pewnej kulturze, oraz od celu przyjętego przez tłumacza. Niemniej z perspektywy inżyniera, prawnika, a nawet osoby posługującej się danym urządzeniem przekład może być oceniany inaczej. Wystarczy, że tłumacz dąży do uzyskania dobrej jakości wypowiedzi w języku docelowym, a odbiorca chce profesjonalnej informacji, albo odwrotnie - tłumacz przełożył wszystko zgodnie z wymogami danej specjalności, ale odbiorca nic $\mathrm{z}$ tego nie rozumie, bo nie jest technikiem i przekład instrukcji obsługi danego sprzętu jest dla niego niejasny. Niezgodne mogą więc być cele translacji zakładane przez translatora i odbiorcę, a także krytyka (badacza). W wypadku literatury pięknej najlepszym przykładem wydaje się reakcja cenzury na dany, przełożony już tekst, kiedy okazuje się, że cele autora oryginału są nie do przyjęcia dla wydawcy bądź innego decydenta. Może to dotyczyć również tekstów innego rodzaju, choćby reklamowych.

Jednak $\mathrm{z}$ drugiej strony odpowiedź na pytanie o różne perspektywy badawcze powinna brzmieć NIE, a wynika to z mojej wewnętrznej niezgody na konieczność wyboru perspektywy, która, jak wspomniałam, w wypadku tłumacza powinna odpowiadać specyfice tekstu i być zgodną z zasadami obowiązującymi w danej kulturze i w danej epoce. Nie może więc być inna niż perspektywa współczesnego mu odbiorcy. Inaczej mówiąc, tłumacz musi brać pod uwagę potencjalnego odbiorcę swego tekstu, szczególnie w wypadku tekstu użytkowego. Z kolei perspektywa krytyka powinna te aspekty uwzględniać. W przeciwnym razie nieustannie będą toczyć się spory wynikające $\mathrm{z}$ innej perspektywy przyjętej np. przez translatora i badacza, jak w wypadku znanej dyskusji Stanisława Barańczaka z polskim przekładem Sonetu X Johna Donne'a autorstwa Jerzego Sity [Barańczak 1990: 40-44], gdzie perspektywy pierwszego thumacza (Sity) i kolejnego translatora, a zarazem krytyka (Barańczaka) były różne, choć w tym konkretnym wypadku nie chodziło 
o perspektywę interdyscyplinarną, lecz raczej o stosunek do stopnia archaizacji przełożonego tekstu, o czym pisał swego czasu Piotr Wilczek [Wilczek 2011: 19-30].

Kończąc niniejsze rozważania, chciałabym wrócić do problemu zaistnienia przekładoznawstwa jako niezależnej dziedziny naukowej, co wielokrotnie postulowano i o co zwracano się już do właściwych władz oraz decydentów. Z mojej perspektywy potrzeba uznania przekładoznawstwa wydaje się oczywista. Wielokrotnie bowiem uświadamiano mi, że nie jestem ani lingwistą, ani literaturoznawcą, co wymusza na mnie funkcjonowanie w nierzeczywistej rzeczywistości. Jednak o ile mogę pozytywnie odpowiedzieć na pytanie, jak być powinno, o tyle trudno mi przewidzieć szanse urzeczywistnienia tego postulatu naszego środowiska.

Nie chcę mówić w tym miejscu o naszej, jako środowiska, niemocy, wolę zastanawiać się nad pracą w istniejącej rzeczywistości i wyrazić nadzieję, że brak oficjalnego uznania przekładoznawstwa za samodzielną dziedzinę naukową nie przeszkodzi w jej rozwoju.

Mimo oficjalnego nieistnienia zaistniała ona w polskiej nauce, stale pojawiają się kolejni, zainteresowani tą problematyką badacze, organizowane są liczne konferencje poświęcone tej nieoficjalnej dziedzinie nauki. Dlatego pozwolę sobie powtórzyć jeszcze raz: nic nie zmienia rzeczywistości badawczej, a ta pozwala nam mówić o jednorodnej, choć wykorzystującej inne dziedziny dyscyplinie naukowej zorientowanej na badanie przekładu.

Nie znaczy to, że nie trzeba próbować, przeciwnie - należy ponawiać apele o jej oficjalne uznanie i jednoczyć się dla tej sprawy niezależnie od swoich perspektyw badawczych, mniej lub bardziej językoznawczych, literaturoznawczych, kulturoznawczych, socjologicznych, odwołujących się do odmiennych tradycji tłumaczenia, zależnych od rodzaju tekstu i od specyfiki różnych filologii, co charakteryzuje tę dyscyplinę łączącą wymiar interdyscyplinarny z odrębnością podmiotu badawczego.

\section{Bibliografia}

Balcerzan, E. (2009), Tłumaczenie jako „,wojna światów”. W kręgu translatologii i komparatystyki, Wydawnictwo Naukowe UAM, Poznań.

Barańczak, S. (1990), „Mały, lecz maksymalistyczny Manifest translatologiczny albo: Tłumaczenie się z tego, że tłumaczy się wiersze również $\mathrm{w}$ celu 
wytłumaczenia innym tłumaczom, iż dla większości tłumaczeń wierszy nie ma wytłumaczenia", Teksty Drugie. 3: 7-66.

Grosbart, Z. (1996), „Niektóre aspekty nauki o thumaczeniu”, [w:] Jerzy Snopek, red. Ttumaczenie. Rzemiosto i sztuka, Węgierski Instytut Kultury, Warszawa, 57-66.

Grosbart, Z. (1998), „Przesłanki opracowania 'użytecznej' teorii przekładu”, [w:] Piotr Fast, red. Przektad artystyczny a wspótczesne teorie translatorskie, „Śląsk” Wydawnictwo Naukowe, Katowice, 47-55.

Grosbart, Z. (1999), „Cóż to jest przekład? Pytanie prawie mistyczne”, [w:] Piotr Fast, red. Krytyka przekładu w systemie wiedzy o literaturze, „Śląsk” Wydawnictwo Naukowe, Katowice, 7-24.

Kielar, B. Z. (1988), Thumaczenie i koncepcje translatoryczne, Zakład Narodowy im. Ossolińskich, Warszawa.

Klonowicz, T. (1992), Stres w Wieży Babel. Różnice indywidualne a wysiłek inwestowany $w$ trudna prace umysłowa, Zakład Narodowy im. Ossolińskich, Wrocław.

Pieńkos, J. (1993), Przekład i ttumacz we wspótczesnym świecie. Aspekty lingwistyczne i pozalingwistyczne, PWN, Warszawa.

Torop, P. (2008), Przektad catkowity, [w:] P. Ricoeur, P. Torop, O thumaczeniu (tłum. Tomasz Swoboda, Stanisław Ulaszek), Wydawnictwo UG, Gdańsk, 63-320.

Voellnagel, A. (1973), Jak nie tlumaczyć tekstów technicznych, Wydawnictwa Naukowo-Techniczne, Warszawa.

Wilczek, P. (2011), „John Donne. Polskie przekłady Sonetu X”, [w:] P. Wilczek, red. Angielsko-polskie zwiazki literackie. Szkice o przekładzie artystycznym, „Śląsk” Wydawnictwo Naukowe, Katowice, 19-33.

Ziomek, J. (1965), Staff i Kochanowski: próba zastosowania teorii informacji w badaniach nad przektadem, Wydawnictwo Naukowe UAM, Poznań.

Райс, К. (1978), „Классификация текстов и методы перевода”, [в:] Вилен Наумович Комиссаров, ред. Вопросы теории перевода в зарубежной лингвистике. Сборник статей, Международные отношения, Москва, 202-228.

Макаренко, С. (2002), Судьбы разорванная нить, Главы из недописанной книги, http://www.peoples.ru/family/children/efron-tsvetaeva.

Тюпа, В. И. (2001), Аналитика художественного (введение в литературоведческий анализ), Лабиринт, РГГУ, Москва. 
Веселова, Н. А. (1998), Заглавие литературно-художественного текста: онтология и поэтика, диссертация канд. филол. наук, Тверь, Твер. гос. ун-т, Каф. теории литературы, Тверь.

Векслер М. Е., Саврасов А. К., Репин И. Е. (2011), Экологическое одностишие, [w:] М. Е. Векслер, Песня о страусе Иронические стихи и миниатюры, Эксмо, Одесса, https://books.google.pl/books?id=yX7MAAAAQB AJ\&pg $=$ PT293\&lpg $=$ PT293\&dq $=\# \mathrm{v}=$ onepage $\& q \& \mathrm{f}=$ false.

Makarienko, S. (2002), Sud'by razorwannaja nit', Gławy iz niedopisannoj knigi, http://www.peoples.ru/family/children/efron-tsvetaeva.

Rajs, K. (1978), „Kłassifikacyja tiekstow i mietodypieriewoda”, [w:] Wilen Naumowicz Komissarow, ried. Woprosy tieorii pieriewoda $w$ zarubieżnoj lingwistikie. Sbornik statiej, Mieżdunarodnyje otnoszenija, Moskwa.

Tiupa, W. I. (2001), Analitika chudożestwiennogo (wwiedienije w litieraturowiedczeskij analiz), Łabirint, RGGU, Moskwa.

Wiesiełowa, N. A. (1998), Zagławije litieraturno-chudożestwiennogo tieksta: ontołogija i poetika, dissiertacyja kand. fiłoł. nauk, Twier', Twier. gos.un-t, Kaf. tieorii litieratury, Twier'.

Wieksler M. Je., Sawrasow A. K., Riepin I. Je. (2011), Ekołogiczeskoje odnostiszyje, [w:] M. Je. Wieksler, Piesnia o strausie Ironiczeskije stichi i miniatiury, Eksmo, Odiessa, https://books.google.pl/books?id=yX7MAAAAQBAJ\&p$\mathrm{g}=\mathrm{PT} 293 \& \operatorname{lpg}=\mathrm{PT} 293 \& \mathrm{dq}=\# \mathrm{v}=$ onepage $\& \mathrm{q} \& \mathrm{f}=$ false .

\section{Spis ilustracji}

1. George Dawe, Portret A. A. Tuczkowa IV, Wojskowa Galeria Pałacu Zimowego, Ermitaż, Sankt Petersburg, https://commons.wikimedia.org/w/index. php?curid=1685949.

2. Natalia Koczetkowa (fot.), zdjęcie Mariny Cwietajewej i Siergieja Efrona, 1911.

3. Zdjęcie Siergieja Efrona, 1915.

4. А. Саврасов, Грачи прилетели, http://alexey-savrasov.ru/kartina/1.php.

5. И. Репин, Не ждали, http://www.tanais.info/art/repin40more.html.

\section{STRESZCZENIE}

Artykuł podejmuje próbę odpowiedzi na niektóre pytania dotyczące problematyki przekładu w kontekście interdyscyplinarności tekstu i przekładoznawstwa. Zarówno w dyskusji dotyczącej kwestii przekładu, jak 
i przekładoznawstwa pojawia się pewien chaos terminologiczny. Autorka niniejszej pracy uważa, że tłumacz powinien wykazać się wiedzą z różnych dyscyplin (w zależności od tekstu) i podaje przykłady z praktyki translatorskiej. Zdaniem Autorki rzeczywistość badawcza dowodzi, że w wypadku przekładoznawstwa mamy do czynienia z jednorodną (choć wykorzystującą zdobycze innych obszarów wiedzy), opartą o badania dyscypliną naukową.

Słowa kluczowe: thumaczenie, poezja, przekład intersemiotyczny, polisemiotyzm, intertekst

\section{Abstract \\ Interdisciplinarity and Translation - A Few Possible Answers}

The article attempts to answer some of the questions regarding problems of translation in context of interdisciplinarity of the text and the science of translation. A certain ,terminological chaos” accompanying both the discussion about the translation and translatology has been indicated. The author believes that the translator needs to have knowledge of various disciplines (depending on the type of the text), which she proves by quoting examples from translation practice. She also thinks that in case of science of translation, the research reality allows us to speak about a homogeneous, though using other disciplines, research-oriented scientific discipline.

Keywords: translation, poetry, intersemiotical translation, polisemiotizm, intertext 